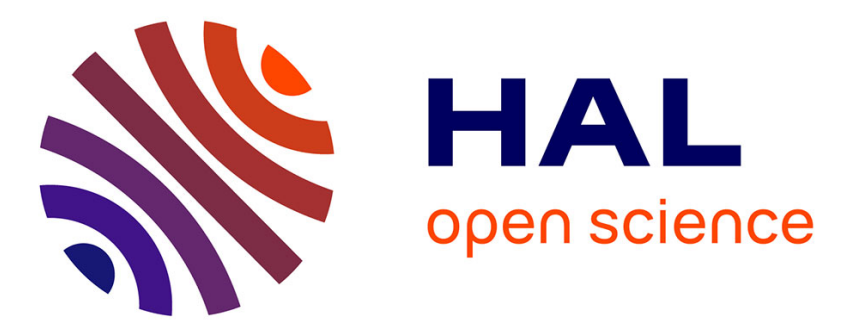

\title{
Development of a rapid, specific and efficient procedure for the determination of proteolytic activity in dry-cured ham: Definition of a new proteolysis index
}

\author{
Rami Harkouss, Pierre-Sylvain Mirade, Philippe P. Gatellier
}

\section{- To cite this version:}

Rami Harkouss, Pierre-Sylvain Mirade, Philippe P. Gatellier. Development of a rapid, specific and efficient procedure for the determination of proteolytic activity in dry-cured ham: Definition of a new proteolysis index. Meat Science, 2012, 92 (2), pp.84-88. 10.1016/j.meatsci.2012.04.017 . hal02645778

\section{HAL Id: hal-02645778 \\ https://hal.inrae.fr/hal-02645778}

Submitted on 29 May 2020

HAL is a multi-disciplinary open access archive for the deposit and dissemination of scientific research documents, whether they are published or not. The documents may come from teaching and research institutions in France or abroad, or from public or private research centers.
L'archive ouverte pluridisciplinaire $\mathbf{H A L}$, est destinée au dépôt et à la diffusion de documents scientifiques de niveau recherche, publiés ou non, émanant des établissements d'enseignement et de recherche français ou étrangers, des laboratoires publics ou privés. 


\title{
Development of a rapid, specific and efficient procedure for the determination of proteolytic activity in dry-cured ham: Definition of a new proteolysis index
}

\author{
Rami Harkouss, Pierre-Sylvain Mirade, Philippe Gatellier * \\ INRA, UR370 Qualité des Produits Animaux, F-63122 Saint-Genès-Champanelle, France
}

\section{A R T I C L E I N F O}

\section{Article history:}

Received 7 February 2012

Received in revised form 11 April 2012

Accepted 13 April 2012

\section{Keywords:}

Dry-cured ham

Proteolysis index

Fluorescamine

Fluorescence

\begin{abstract}
A B S T R A C T
A method was adapted to determine proteolytic activity in dry-cured ham using fluorescamine-specific labelling of N-terminal $\alpha$-amino groups of peptides and amino acids. Fluorescence of the complex was measured using a microplate procedure and optimum excitation and emission wavelengths of $375 \mathrm{~nm}$ and $475 \mathrm{~nm}$, respectively. A new proteolysis index (PI) was defined as the percentage ratio of the $\mathrm{N}$-terminal $\alpha$-amino group content to the total protein content of the ham extract. The robustness of the method was evaluated by measuring PI in pork meat samples subjected to standardized processing conditions and in samples extracted from industrial hams taken at different stages of processing. For the industrial samples, a comparison with the classic nitrogen procedure of PI determination was performed and a formula relating the two PIs was established. The rapidity, sensitivity and specificity of the procedure make it a good candidate for a screening test to evaluate ham quality in industry.
\end{abstract}

(C) 2012 Elsevier Ltd. All rights reserved

\section{Introduction}

In dry-cured ham, one of the main factors affecting final product quality is proteolytic activity. It impacts the flavour, the appearance (e.g. tyrosine crystals, white film, brightness), and the texture (e.g. hardness, cohesiveness, and springiness) of the product (Arnau, Guerrero, \& Sárraga, 1998; García-Garrido, QuilesZafra, Tapiador, \& Luque de Castro, 2000; Toldrá \& Flores, 2000; Virgili, Parolari, Schivazappa, Bordini, \& Borri, 1995; Zhao et al., 2008). Proteolytic activity depends on many factors, such as $\mathrm{pH}$, water content, $\mathrm{NaCl}$ content and drying conditions (Arnau, Gou, \& Comaposada, 2003; Arnau, Gou, \& Guerrero, 1994; Arnau, Guerrero, \& Gou, 1997; Arnau, Guerrero, Maneja, \& Gou, 1992; Martín, Córdoba, Antequera, Tímon, \& Ventanas, 1998; Toldrá, Flores, \& Sanz, 1997). In dry-cured ham, a proteolysis index (PI), defined as the percentage ratio of non-protein nitrogen content to total nitrogen content, is widely used to characterize the intensity of proteolytic activity; nitrogen content is determined by the Kjeldahl method, which measures ammonia after mineralization of the organic matter (Careri et al., 1993; Ruiz-Ramírez, Arnau, Serra, \& Gou, 2006; Schivazappa et al., 2002). Although this procedure is commonly used and is standardized (ISO 937-1978 E reference method), it has many drawbacks. It is time- and productconsuming, and it lacks specificity, as there are many nitrogen compounds in meat (ammonium salts, urea, uric acid, creatinine,

\footnotetext{
* Corresponding author. Tel.: +33473624198.

E-mail address: pgatel@clermont.inra.fr (P. Gatellier).
}

etc.) that can interfere in the determination of the proteolysis index. A more rapid and efficient assay of peptides and amino acids would thus greatly facilitate the evaluation of proteolysis in dry-cured ham. To this end, a simple, specific fluorometric procedure was developed to determine the level of $\mathrm{N}$-terminal $\alpha$-amino groups of peptides and amino acids, which reflects the intensity of proteolytic activity during the curing process. The procedure is based on the fluorescamine-specific labelling of the $\mathrm{N}$-terminal $\alpha$-amino groups present in the fractions of the ham extracts soluble in $10 \%$ trichloroacetic acid (TCA). A new proteolysis index was then defined as the percentage ratio of the $\mathrm{N}$-terminal $\alpha$-amino group content to the total protein content of the ham extract. Because of the high sensitivity of fluorometric detection, fluorescamine has been extensively used for the quantification of amino acids, peptides and proteins (Bantan-Polak, Kassai, \& Grant, 2001; Castell, Cervera, \& Marco, 1979; Friguet, Stadtman, \& Szewda, 1994; Lorenzen \& Kennedy, 1993; Miedel, Hulmes, \& Pan, 1989). In this study, this fluorophore was used to evaluate the proteolysis of skeletal muscle myofibrillar proteins (Morzel, Gatellier, Sayd, Renerre, \& Laville, 2006).

The first objective of this study was to test the applicability of this procedure to the analysis of proteolysis in dry-cured ham at different stages of processing. For this purpose, determinations were performed in small laboratory samples of pork meat processed under well-defined salting and drying conditions, and in industrial drycured hams. The second objective was to compare this new procedure with the commonly used nitrogen content procedure and to establish an equation which allows converting the new proteolysis index to the classic one. 


\section{Materials and methods}

\subsection{Preparation of the laboratory salted and dried pork meat samples}

This preparation mimicked the different steps used in industry processing, but was adapted to small samples. Three different muscles, biceps femoris (BF), semitendinosus (ST), and semimembranosus (SM) from a single animal, were used in the preparation of the samples. $\mathrm{pH}_{24 \mathrm{~h}}$ were 5.8 for BF, 5.7 for ST, and 5.6 for SM. First, muscle surfaces were decontaminated by using $0.1 \%$ peracetic acid for $3 \mathrm{~min}$ followed by a $1 \mathrm{~min}$ rinse with sterile water. This operation was repeated twice. The muscle superficial layers damaged by the acid treatment were discarded, and samples were cut into small parallelepipeds $(5 \times 4 \times 0.3 \mathrm{~cm})$. These operations were performed under sterile air using sterile tools. The small pork meat samples were then salted by covering the surface of the piece with a 300 g.L $\mathrm{L}^{-1} \mathrm{NaCl}$ solution using a multichannel pipette (Multipette plus, Eppendorf AG, Hamburg, Germany) adjusted to $4 \mu \mathrm{l}$ per spot. In these conditions, salt diffused so as to achieve a homogenous distribution in a few hours. The quantity of salt added was calculated on the basis of the salt concentration (4\% to $13 \%$ of the dry matter) and water content (50\% to $75 \%$ ) required in the final pork meat samples. The percentages of salt obtained in the different samples were always contained between the expected percentage, by $-1 \%$ to $+1 \%$, and the mean values calculated on four samples were close to the expected ones. Drying was then performed at $15^{\circ} \mathrm{C}$ for different times (up to $16 \mathrm{~h}$ for the driest samples) until each sample reached the weight corresponding to the selected water content. After checking the water content by determining the dry matter and salt content by chlorometry (MKII Chloride Analyser 926, Sherwood, Cambridge, UK), samples were placed under vacuum in plastic bags and kept in temperature-controlled chambers (Model $14 \mathrm{D}-78532$, Binder $\mathrm{GmbH}$, Tuttlingen, Germany) at different temperatures $\left(4{ }^{\circ} \mathrm{C}, 14.5^{\circ} \mathrm{C}\right.$ and $\left.25^{\circ} \mathrm{C}\right)$ to obtain various proteolysis kinetics. At the end of the processing, samples were stored at $-80^{\circ} \mathrm{C}$ until analysed. Four samples were prepared for each processing condition.

\subsection{Preparation of the samples extracted from industrial dry-cured hams}

PI determinations were performed on Bayonne dry-cured hams. Bayonne ham obtained a Protected Designation of Origin (PDO) certification in 1998 and its characteristics have been described by Robert and Lanore (2003). Three muscles (biceps femoris, semitendinosus, and semimembranosus) were extracted from three different hams at the end of each main processing stage, i.e. the resting period ( 11 weeks), drying period ( 21 weeks), and ageing period (12 months). Samples were taken from each muscle to calculate the new proteolysis index, allowing 24 determinations per muscle type per time ( 3 hams $\times 8$ samples). For the calculation of the classic proteolysis index, only one sample weighing about $50 \mathrm{~g}$ was taken from each muscle of the three hams. Some physical and chemical characteristics of these Bayonne hams $(\mathrm{pH}$, water content and salt content) were determined (Table 1 ).

\subsection{Determination of the new proteolysis index}

Pork meat samples were placed for $1 \mathrm{~h}$ in cold water $(0.7 \mathrm{~g}$ in $7 \mathrm{ml}$ ) to facilitate subsequent grinding. Extracts from the pork samples were prepared by homogenization with a Polytron PTMR 2100 (Kinematica AG, Switzerland) for $30 \mathrm{~s}$ at maximum speed $(30,000 \mathrm{rpm}) ; 150 \mu \mathrm{l}$ aliquots of the extract were then removed and diluted with $600 \mu \mathrm{l}$ of $12.5 \%$ trichloroacetic acid to precipitate proteins (TCA final concentration 10\%). Samples were shaken for $15 \mathrm{~min}$ at $4{ }^{\circ} \mathrm{C}$. After centrifuging at $2000 \mathrm{~g}$ for $10 \mathrm{~min}$, the concentration of peptides and amino acids in the
Table 1

Characteristics of the Bayonne dry-cured hams at the end of each main processing stage. Water and $\mathrm{NaCl}$ contents were calculated on the basis of the total and dry matter, respectively. Values were the means $+/$ - SEM of 3 determinations (one determination per muscle). Values not bearing common superscripts differ significantly $(p<0.05)$.

\begin{tabular}{lllll}
\hline & & $\mathrm{pH}$ & Water content (\%) & $\mathrm{NaCl}$ content (\%) \\
\hline \multirow{2}{*}{11 weeks } & SM & $5.85+/-0.05 \mathrm{a}$ & $69.8+/-0.6 \mathrm{ab}$ & $2.67+/-0.42 \mathrm{ab}$ \\
& $\mathrm{ST}$ & $5.95+/-0.09 \mathrm{a}$ & $68.0+/-0.1 \mathrm{a}$ & $4.63+/-0.13 \mathrm{a}$ \\
\multirow{5}{*}{21 weeks } & $\mathrm{BF}$ & $5.90+/-0.04 \mathrm{a}$ & $71.6+/-0.2 \mathrm{~b}$ & $2.39+/-0.28 \mathrm{~b}$ \\
& $\mathrm{SM}$ & $5.88+/-0.11 \mathrm{a}$ & $61.1+/-1.2 \mathrm{a}$ & $3.38+/-0.47 \mathrm{a}$ \\
& $\mathrm{ST}$ & $5.87+/-0.11 \mathrm{a}$ & $65.3+/-1.0 \mathrm{ab}$ & $3.40+/-0.54 \mathrm{a}$ \\
& $\mathrm{BF}$ & $5.95+/-0.13 \mathrm{a}$ & $68.2+/-0.5 \mathrm{~b}$ & $3.72+/-0.59 \mathrm{a}$ \\
& $\mathrm{SM}$ & $5.68+/-0.05 \mathrm{a}$ & $56.4+/-1.0 \mathrm{a}$ & $4.94+/-0.22 \mathrm{a}$ \\
& $\mathrm{ST}$ & $5.78+/-0.03 \mathrm{a}$ & $57.2+/-1.4 \mathrm{a}$ & $5.41+/-0.26 \mathrm{a}$ \\
& $\mathrm{BF}$ & $5.83+/-0.03 \mathrm{a}$ & $60.5+/-0.7 \mathrm{a}$ & $5.72+/-0.33 \mathrm{a}$ \\
\hline
\end{tabular}

supernatant was measured by the method of Friguet et al. (1994) with slight modifications. First, $300 \mu$ of the supernatant was neutralized with $300 \mu \mathrm{l}$ of $2 \mathrm{M}$ sodium borate, $\mathrm{pH} 10$. In these conditions, the final $\mathrm{pH}$ of the solution was $9.2+/-0.1$, a value suitable for the reaction with fluorescamine. Secondly, $180 \mu$ of fluorescamine (Sigma) at a concentration of $0.6 \mathrm{mg} \cdot \mathrm{ml}^{-1}$ in acetone was added. Free fluorescamine does not fluoresce, but its reaction with primary amines yields a fluorescent pyrolinone moiety. Fluorescence was measured $1 \mathrm{~h}$ after adding fluorescamine by means of a Perkin-Elmer LS 50B spectrofluorometer. A front surface accessory (Perkin Elmer Plate Reader) was installed for measurement in 96-well polystyrene microplates designed for fluorescence. A volume of $200 \mu \mathrm{l}$ was placed in each well. Analyses were performed at the optimum excitation and emission wavelengths $\left(\lambda_{\text {excitation }}=375 \mathrm{~nm}\right.$ and $\lambda_{\text {emission }}=475 \mathrm{~nm}$ ) with excitation and emission slit setting to $10 \mathrm{~nm}$. The non-specific fluorescence of corresponding fluorescamineuntreated samples was subtracted. The level of amino groups in the pork meat extracts was determined by reference to a calibration curve of glycine from $5 \mathrm{mM}$ to $50 \mathrm{mM}$ (concentration of the stock solution before TCA treatment) treated under exactly the same conditions and at the same time as the pork meat extracts. Fig. 1 shows that fluorescence increased linearly with glycine throughout the range of concentrations used $\left(R^{2}=0.993\right)$. The level of $\mathrm{N}$-terminal $\alpha$ amino groups was then expressed in grams of "glycine equivalent" per gram of ham $(A)$. In parallel, the total protein content was estimated in the pork meat extract, before treatment, by the biuret method (Gornall, Bardawill, \& David, 1949). Results were expressed in grams of protein per gram of ham (B). The new proteolysis index was then expressed as the percentage

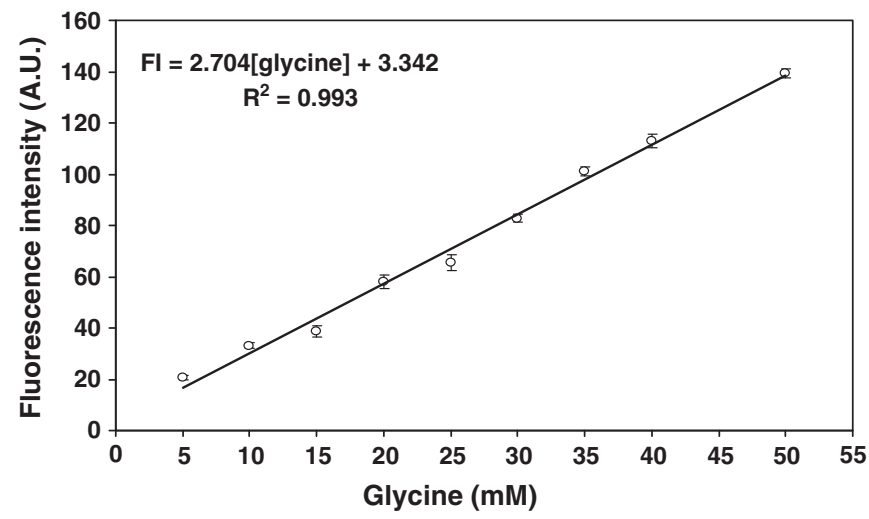

Fig. 1. Calibration curve of glycine with fluorescamine. Glycine concentrations were those of the initial stock solutions before the TCA treatment. Values were the means $+/-$ SEM of four independent determinations. 
ratio of $\mathrm{N}$-terminal $\alpha$ amino group content to total protein content according to:

$\mathrm{PI} \%=(\mathrm{A} / \mathrm{B}) \times 100$.

\subsection{Determination of the classic nitrogen proteolysis index}

Total nitrogen (TN) was determined by the Kjeldahl method according to the ISO 937-1978(E) reference method, and nonprotein nitrogen (NPN) content by precipitation of proteins with TCA followed by determination of nitrogen in the extract by the Kjeldahl method. The proteolysis index was determined as the percentage ratio of NPN to TN (Careri et al., 1993; Ruiz-Ramírez et al., 2006, Schivazappa et al., 2002).

\subsection{Statistics}

ANOVA was performed at the end of the resting, drying and ageing periods to test the effects of the processing periods and muscle types on the PI values. When a significant effect was observed by ANOVA, the unpaired Student $t$-test was used to determine the statistical significance between groups.

\section{Results}

3.1. Determination of the new proteolysis index in laboratory-dried and salted pork meat samples

The applicability of the new procedure to characterize proteolysis kinetics was tested first in different samples processed under welldefined salting and drying conditions. The use of small pork meat samples enabled the testing of a large number of conditions in muscles of a single animal, thus circumventing lack of reproducibility due to animal effect. In this case, PI variation cannot be produced by differences in raw material (protease activity, inhibitors, pH, etc.). Another advantage of reducing the product size is that rapid salt diffusion and drying, considerably shortens preparation time (16 $\mathrm{h}$ at the most). A large number of conditions (salting, drying, temperature, time, and muscle type) were tested, but the complete results will be presented and discussed in a forthcoming paper. The purpose of the present work was only to illustrate the potential of the new procedure for PI determination in a restricted number of conditions and in one muscle only.

The initial value of PI, measured in the biceps femoris muscle before processing, was very low $(1.04 \%+/-0.33 \%)$. In Fig. 2 the time course of the PI in pork meat samples prepared from muscle biceps

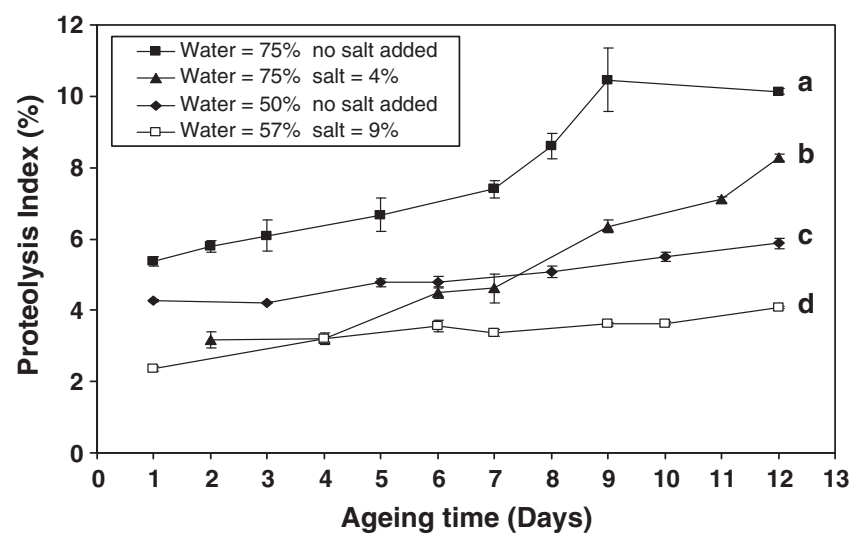

Fig. 2. Proteolysis kinetics in M. Biceps femoris at $25^{\circ} \mathrm{C}$ under different processing conditions. Values were the means $+/-$ SEM of four independent determinations. At the end of ageing, values not bearing common superscripts differ significantly $(p<0.001)$. femoris and stored under vacuum for 12 days at $25{ }^{\circ} \mathrm{C}$ is seen. The mean coefficient of variation (ratio of standard deviation to mean value) of this parameter calculated from all conditions was 5.3\%, demonstrating the good reproducibility of the procedure. Fig. 2 shows that the untreated samples (75\% water and no salt added) exhibited the highest proteolysis index. In this case PI reached a maximum of $10.5 \%$ after 9 days of ageing and remained stable for the following 3 days of ageing. Salting alone (to $4 \%$ of the dry matter) and drying alone (to $50 \%$ of water content) reduced the proteolysis intensity. This effect was much more pronounced when both salting and drying processes were applied ( $9 \%$ salt and $57 \%$ water). In this case a $60 \%$ decrease in PI value was observed after 12 days of ageing, compared with the untreated samples. After 12 days of ageing, the four conditions tested exhibited significant differences in PI values $(p<0.001)$. At lower temperatures $\left(14.5^{\circ} \mathrm{C}\right.$ and $\left.4{ }^{\circ} \mathrm{C}\right)$, the PI increase was considerably reduced (data not shown). These results were in line with those generally reported in demonstrating a decrease in proteolysis activity with increasing salt content (Martín et al., 1998; Robert \& Lanore, 2003; Ruiz-Ramírez et al., 2006) and with decreasing temperature (Martín et al., 1998; Robert \& Lanore, 2003) or water content (Toldrá, Cerveró, \& Part, 1993; Toldrá et al., 1997).

\subsection{Determination of the new proteolysis index in industrial dry-cured ham samples}

The applicability of the new procedure to the characterization of proteolysis kinetics was then tested in more realistic conditions by measuring PI in industrial Bayonne hams over a 12-month period (Fig. 3). Probably owing to the animal effect, the mean coefficient of variation of PI, calculated over the whole conditions, was higher than calculated in laboratory-dried and salted pork meat samples derived from the same animal (19.6\% vs. 5.3\%). To characterize the kinetics of proteolysis, the increase in PI with time was fitted by a second-order polynomial regression. Despite the biological variability, good correlation coefficients were obtained from the different curves $\left(R^{2}>0.99\right)$. As seen in Fig. 3, the three muscles tested can be ranked in order of increasing proteolysis speed: $\mathrm{BF}>\mathrm{SM}>\mathrm{ST}$. BF and SM did not display any significant differences in terms of proteolysis intensity, while proteolysis in ST was always lower than in BF and SM. In the case of the BF muscle, a proteolysis increase of $2200 \%$ was observed during the overall period and of 55\% during the ageing period only. These results were in line with those of Zhao et al. (2008), who reported a PI increase in BF muscle of 60\% during the last 7 months of ageing. Ruiz-Ramírez et al. (2006) and Toldrá et al. (1997) also reported higher proteolysis in BF than in SM muscle. Like these authors, the higher proteolysis in the BF muscle can be

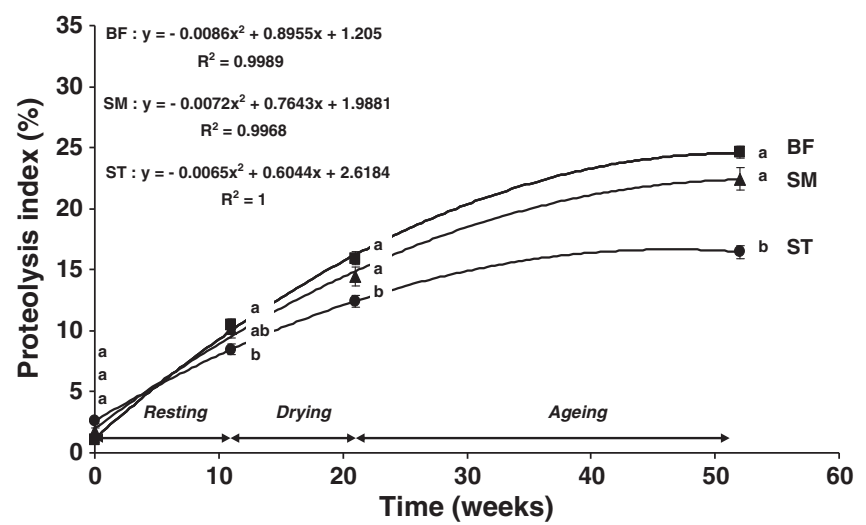

Fig. 3. Proteolysis kinetics in three muscles of different Bayonne dry-cured hams. The zero time values corresponded to PI in the unsalted raw meats. Values were the means $+/-$ SEM of 24 determinations. Values not bearing common superscripts differ significantly $(p<0.05)$. 


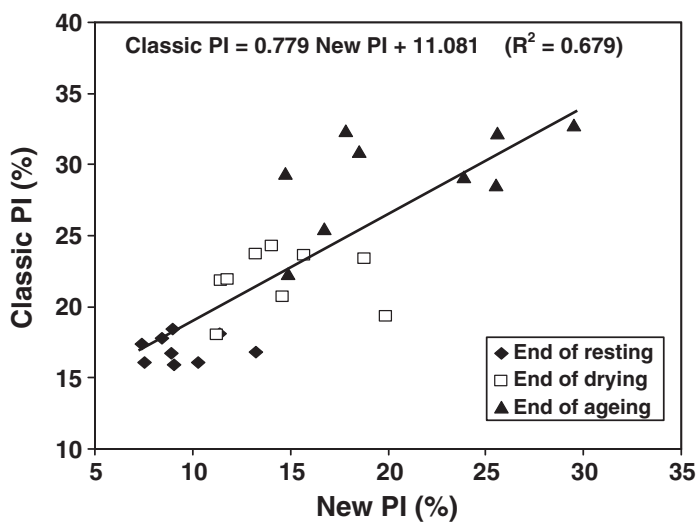

Fig. 4. Relationship between the classic proteolysis index (nitrogen index) and the new proteolysis index (fluorescamine index).

attributed to its higher residual moisture content (Table 1), which allows a higher activity of endogenous proteases. Differences between SM and ST muscles could be explained by the fact that for similar water content, ST muscle had higher salt contents (Table 1).

\subsection{Relationship between the classic and the new proteolysis indices}

Most of the data on dry-cured ham proteolysis have been gained with the classic nitrogen proteolysis index, and so industrial operators use this index routinely. Hence although we have demonstrated the applicability of this new procedure in different conditions has been demonstrated and its many advantages compared with the classic procedure (Section 4. discussion), to be accepted in the dry-cured ham industry, the new proteolysis index must be easily convertible into the classic index. For this purpose, a conversion equation was established by comparison of the two indices in these same Bayonne hams at the end of the resting, drying and ageing periods. Fig. 4 shows the relation between the two PIs. The relationship was well fitted with a linear regression model:

$\mathrm{PI}_{\text {classic }}=0.779 \mathrm{PI} \mathrm{I}_{\text {new }}+11.081(r=0.824, p<0.001)$

Clearly, this conversion formula is valid only so long as the determinations are performed in the conditions described above (Sections 2.3 and 2.4). Other protocols will require new formulas.

\section{Discussion}

This new procedure of PI determination offers many advantages over the classic nitrogen procedure. The fluorometric detection lends it a high sensitivity, which allows work on very small product quantities. Samples of $0.7 \mathrm{~g}$ were used in the present study, but we have successfully tested this procedure with smaller quantities of meat (less than $0.1 \mathrm{~g}$, data not shown). Using this procedure, dry-cured hams could be tested during industrial fabrication by punching a small hole in the muscle, without depreciation of the products. In addition, the procedure is rapid; the use of a microplate reader allows fluorescence measurement of 96 samples in less than $1 \mathrm{~min}$. The limiting factor in the procedure is the muscle extract preparation, but with trained personnel more than 50 determinations can be performed daily. This procedure also offers high specificity; fluorescamine does not react with the major non-protein nitrogenous substances commonly present in muscle, i.e. urea, uric acid, creatinine and ammonia (Klein \& Standaert, 1976). Fluorescamine can react with the $\varepsilon$-amino groups of lysine (Dhaunta, Fatima, \& Guptasarma, 2011), which are not specific products of proteolysis. To avoid this, conditions were chosen such that the reaction of fluorescamine with amino groups was specific for adduction of fluorescamine only to the $\mathrm{N}$-terminal $\alpha$-amino groups.
The reaction with fluorescamine requires the amino group to be in its unprotonated form (Bantan-Polak et al., 2001; Bohlen, Stein, \& Udenfriend, 1974; Castell et al., 1979; Mendez \& Gavilanes, 1976). Since the $\mathrm{p} K_{\mathrm{a}}$ of the $\mathrm{N}$-terminal $\alpha$-amino groups of peptides (8.0) is lower than the $\mathrm{p} K_{\mathrm{a}}$ of lysine $\varepsilon$-amino groups (10.8) (Berg, Tymoczko, \& Stryer, 2007), conjugation of the label to the lysine compared with the $\mathrm{N}$-terminal $\alpha$-amino groups was minimised by performing the labelling reaction at $\mathrm{pH} 9.2$; using the Henderson equation, at $\mathrm{pH} 9.2$, $94 \%$ of the $\mathrm{N}$-terminal $\alpha$-amino groups were in the reactive unprotonated form $\left(\mathrm{NH}_{2}\right)$, while the $\varepsilon$-amino groups of lysine were almost entirely (98\%) in the non-reactive protonated form $\left(\mathrm{NH}_{3}^{+}\right)$. It was for that very reason that in peptides containing lysine residues, Dhaunta et al. (2011) failed to detect any evidence of labelling of this residue with fluorescamine in the $\mathrm{pH}$ range 8.0 to 10.0. Also, fluorescamine does not react with secondary amines such as the amino groups of histidine and arginine side chains (Dhaunta et al., 2011; Weigele, De Bernardo, Tengi, \& Leimgruber, 1972). Finally, it may be safely asserted that the new procedure is more powerful than the classic procedure in that it describes the progress of the proteolytic activity more finely. For example, in the case of the complete degradation of a decapeptide, the classic procedure cannot discriminate between the decapeptide containing 10 nitrogen atoms and the sum of the 10 corresponding amino acids each containing one nitrogen atom. In such a case, the PI remains unchanged. By contrast, the new procedure distinguishes between the decapeptide (one $\mathrm{N}$-terminal $\alpha$-amino group) and the corresponding amino acids ( $10 \mathrm{~N}$-terminal $\alpha$-amino groups). In this case the PI is multiplied by ten.

\section{Conclusion}

Based on these results, the fluorescamine-specific labelling of the $\mathrm{N}$-terminal $\alpha$-amino groups of peptides and amino acids offers a powerful technique to determine proteolysis intensity in dry-cured ham. This procedure is more rapid and more specific than the classic nitrogen procedure. The easy conversion of PI values obtained with this new procedure into the classic PI values allows the fluorescamine method to be used directly in industry as a reference method for PI determination in dry-cured hams.

\section{Acknowledgments}

This work was funded by the Na-integrated programme (ANR-09ALIA-013-01) financed by the French National Research Agency. We thank H. Safa for participating in some of the laboratory work, S Portanguen, L. Aubry and J.D. Daudin for discussing the protocol of preparation of the laboratory pork meat samples, ADIV for measuring the classic PI in industrial Bayonne ham samples, and ATT for language editing.

\section{References}

Arnau, J., Gou, P., \& Comaposada, J. (2003). Effect of the relative humidity and drying air during the resting period on the composition and appearance of dry-cured ham surface. Meat Science, 65, 1275-1280.

Arnau, J., Gou, P., \& Guerrero, L. (1994). The effect of freezing, meat pH, and storage temperature on the formation of white film and tyrosine crystals in dry-cured ham. Journal of the Science of Food and Agriculture, 66, 279-282.

Arnau, J., Guerrero, L., \& Gou, P. (1997). Effects of temperature during the last month of ageing and of salting time on dry-cured ham aged for six months. Journal of the Science of Food and Agriculture, 74, 193-198.

Arnau, J., Guerrero, L., Maneja, E., \& Gou, P. (1992). Effect of pH and genetics on texture characteristics of dry cured ham. 38th ICOMST (pp. 229-232).

Arnau, J., Guerrero, L., \& Sárraga, C. (1998). The effect of green ham $\mathrm{pH}$ and $\mathrm{NaCl}$ concentration on cathepsin activities and sensory characteristics of dry-cured ham. Journal of the Science of Food and Agriculture, 77, 387-392.

Bantan-Polak, T. Kassai, M. \& Grant, K. B. (2001). A comparison of fluorescamine and naphthalene-2,3-dicarboxaldehyde fluorogenic reagents for microplate-based detection of amino acids. Analytical Biochemistry, 297, 128-136.

Berg, J. M., Tymoczko, J. L., \& Stryer, L. (2007). Biochemistry (6th ed.). New York, NY: W.H. Freeman and Company. 
Bohlen, P., Stein, S., \& Udenfriend, S. (1974). Studies on the reaction of fluorescamine with primary amines. Archives of Biochemistry and Biophysics, 163, 390-399.

Careri, M., Mangia, A., Barbieri, G., Bolzoni, L., Virgili, R., \& Parolari, G. (1993). Sensory property relationships to chemical data of Italian dry-cured ham. Journal of Food Science, 58, 968-972.

Castell, J. V., Cervera, M., \& Marco, R. (1979). A convenient micromethod for assay of primary amines and proteins with fluorescamine: a re-examination of the conditions of reaction. Analytical Biochemistry, 99, 379-391.

Dhaunta, N., Fatima, U., \& Guptasarma, P. (2011). N-Terminal sequencing by mass spectrometry through specific fluorescamine labelling of $\alpha$-amino groups before tryptic digestion. Analytical Biochemistry, 408, 263-268.

Friguet, B., Stadtman, E. R., \& Szewda, L. I. (1994). Modification of glucose-6-phosphate dehydrogenase by 4 -hydroxy-2-nonenal. Formation of cross-linked protein that inhibits the multicatalytic protease. Journal of Biological Chemistry, 269, 21639-21643.

García-Garrido, J., Quiles-Zafra, R., Tapiador, J., \& Luque de Castro, M. (2000). Activity of cathepsin B, D, H and L in Spanish dry-cured ham of normal and defective texture. Meat Science, 56, 1-6.

Gornall, A. G., Bardawill, C. J., \& David, M. M. (1949). Determination of serum proteins by means of biuret reaction. Journal of Biological Chemistry, 177, 751-766.

Klein, B., \& Standaert, F. (1976). Fluorimetry of plasma amino nitrogen, with the use of fluorescamine. Clinical Chemistry, 22, 413-416.

Lorenzen, A., \& Kennedy, S. W. (1993). A fluorescent-based protein assay for the use with a microplate reader. Analytical Biochemistry, 214, 346-348.

Martín, L., Córdoba, J. J., Antequera, T., Tímon, M. L., \& Ventanas, J. (1998). Effects of salt and temperature on proteolysis during ripening of iberian ham. Meat Science, 49, 145-153.

Mendez, E., \& Gavilanes, J. G. (1976). Fluorimetric detection of peptides after column chromatography or on paper: o-phthalaldehyde and fluorescamine. Analytical Biochemistry, 72, 473-479.
Miedel, M. C., Hulmes, J. D., \& Pan, Y. C. E. (1989). The use of fluorescamine as a detection reagent in protein microcharacterization. Journal of Biochemical and Biophysical Methods, 18, 37-52.

Morzel, M., Gatellier, Ph., Sayd, T., Renerre, M., \& Laville, E. (2006). Chemical oxidation decreases proteolytic susceptibility of skeletal muscle myofibrillar proteins. Meat Science, 73, 536-543.

Robert, N., \& Lanore, D. (2003). Une mine d'éléments essentiels. Le jambon de Bayonne. Viandes et Produits Carnés, 23, 97-101.

Ruiz-Ramírez, J., Arnau, J., Serra, X., \& Gou, P. (2006). Effect of pH 24, NaCl content and proteolysis index on the relationship between water content and texture parameters in biceps femoris and semimembranosous muscle in dry-cured ham. Meat Science, 72, 185-194.

Schivazappa, C., Degni, M., Nanni-Costa, L., Russo, V., Buttazzoni, L., \& Virgili, R. (2002) Analysis of raw meat to predict proteolysis in Parma Ham. Meat Science, 60, 77-83.

Toldrá, F., Cerveró, M. C., \& Part, C. (1993). Porcine aminopeptidase activity as affected by curing agents. Journal of Food Science, 58, 724-726.

Toldrá, F., \& Flores, M. (2000). The use of muscle enzymes as predictor of pork meat quality. Food Chemistry, 69, 387-395.

Toldrá, F., Flores, M., \& Sanz, Y. (1997). Dry-cured ham flavour: enzymatic generation and process influence. Food Chemistry, 59, 523-530.

Virgili, R., Parolari, G., Schivazappa, C., Bordini, C. S., \& Borri, M. (1995). Sensory and texture quality of dry-cured ham as affected by endogenous cathepsin B activity and muscle composition. Journal of Food Science, 60, 1183-1186.

Weigele, M., De Bernardo, S. I., Tengi, J. P., \& Leimgruber, W. (1972). Novel reagent for the fluorimetric assay of primary amines. Journal of the American Chemical Society, 94, 5927-5928.

Zhao, G. M., Tian, W., Liu, Y. X., Zhou, G. H., Xu, X. L., \& Li, M. Y. (2008). Proteolysis in biceps femoris during Jinhua ham processing. Meat Science, 79, 39-45. 